\title{
Large Scale Land Acquisitions In Sub- Saharan Africa: The New Scramble?
}

\author{
Donald L Sparks, PhD, The Citadel, USA \& Management Center Innsbruck, Austria
}

\begin{abstract}
Almost three-fourths of the world's recent "land grabs" have occurred in sub-Saharan Africa, estimated at some 50 million hectares, which is almost equal to the size of Spain. As most of the recent land acquisitions involve farmland, and since agriculture is so vital to Africa's ability to reduce poverty and hunger, this is a particularly important topic. These large acquisitions raise concerns about the dangers of neglecting local needs and exacerbating social tensions in already fragile states.
\end{abstract}

Keywords: Economic Development; Economic Growth; State-owned Enterprises; Sovereign Wealth Funds; Foreign Direct Investment; Land Tenure; Land Acquisitions; Sub-Saharan Africa; South Africa; Water Rights

\section{INTRODUCTION}

lmost three-fourths of the world's recent "land grabs" have occurred in sub-Saharan Africa, estimated at some 50 million hectares, which is almost equal to the size of Spain (World Bank, 2010; FAO, 2005; Global Land Project, 2010). As most of the recent land acquisitions involve farmland, and since agriculture is so vital to Africa's ability to reduce poverty and hunger, this is a particularly important topic. These large acquisitions raise concerns about the dangers of neglecting local needs and exacerbating social tensions in already fragile states (Coutla et al, 2009; World Bank, 2010).

These land grabs have received intense media and academic attention and from August 2008 to April 2010, there were 236 articles in the press about African land deals (Global Land Project, 2010). In addition, the University of Sussex hosted a major conference - International Conference on Global Land Grabbing - in April 2011, and there have been numerous studies by the FAO, IFAD, World Bank, and others (see references). Nonetheless, despite such work, there are still many gaps in knowledge with little empirical evidence about impacts.

\section{WHERE DEMAND ORIGINATES AND SOME REASONS FOR INCREASING DEMAND}

The principle origins of demand are from the Gulf States of Saudi Arabia, UAE, Qatar, Kuwait and Bahrain, China, South Africa, Japan, Russia, South Korea, the US, and UK and other EU members (Cotula et al, 2009). There are various types of buyers, including state-owned enterprises, sovereign wealth funds, foreign and domestic private sector investors, and central government agencies.

The key drivers behind the recent land grabs include increasing population growth, urbanization and changes in the food tastes in many of these countries, increasing demand for biofuels and, perhaps most importantly, food security (Daniel and Mittal, 2009; Smaler and Mann, 2009; Zoomers, 2010). As these originating countries become more urbanized and wealthier, their demands for beef increases and cattle rising requires massive amounts of grain for feed. The food security concerns from investor countries comes as a result of the food price hikes during 2007-2008 which caused many countries to reconsider their policies to reduce their vulnerability to food imports. These hikes caused social unrest in 33 countries. In addition, rice and wheat yields have stabilized, so the scope for increased yields are lower than in recent years. Also, many government policies are being put in place for food and energy diversification. While there are a variety of reasons causing these spikes, the increased demand for bio-fuels (which reduced the amount of food crops on the world market) was an important catalyst (Mitchell, 2010; Friends of the Earth, 2010). 
Finally, given the world-wide collapse in the housing market and low yields on stock shares, there has been a global vacuum for investment. There have been expectations of increased demand and attendant land prices (although this is not generally a major factor).

There are compelling arguments in the literature suggesting that water is a key driver in the land grab phenomena (Conway and Ardoin, 2009; Rockstrom and Fox, 2003; Smaller and Mann, 2009; Woodhouse and Ganho, 2011). Source countries, such as India and China, have limited renewable water resources. Saudi Arabia has invested in countries with renewable water resources, as evidenced by its seven-year plan to produce seven million tons of rice annually under irrigation on a total of 700,000 ha in Niger, Mali, Senegal, Uganda, and Sudan. Because two-thirds of sub-Saharan Africa lies outside the humid equatorial zone, water is and will remain a key constraint to agricultural growth.

Generally, agriculture in this area (mostly savanna grasslands) is rain-fed, which is highly seasonal (most rain comes within a 4 to 5 -month period) with annual rainfall varying from $400 \mathrm{~mm}$ in the Sahel to $1,200 \mathrm{~mm}$ in the Guinea savanna. Not only is rainfall limited to a few months a year, there is high inter-year variability, resulting in droughts.

Agricultural production will require blue water (rivers, lakes, irrigation) as well as green water (rainfall). Both rice and sugarcane, which require high volumes of rice, generally require irrigation, except in a few very humid climactic zones (Woodhouse, 2011).

Colonial administrations began to "modernize" African agriculture, but most grand schemes - the famous Nigerian ground nut scheme and the large scale cotton projects at Gezira in Sudan, for example - failed (FAO, 2005). As formal irrigation schemes fell out of favor from aid agencies, development NGOs, and private funders, there has been a growing interest in informal water management from African farmers. This has been compounded by a withdrawal of state support, driven by structural adjustment demands or from government austerity measures. Indeed, agricultural development lending fell from 30\% of World Bank loans in 1980 to 12\% in 2010 (World Bank, 2010).

\section{FACTORS ON THE SUPPLY SIDE, NUMBER AND TYPES OF DEALS}

There remains a general perception of vast unused amounts of farmland for the asking, with very low prices. Host countries often offer incentives, including virtually free land (and when charged, payments range from \$3-10 per hectare annually) and tax holidays ostensibly in the expectation of increased employment opportunities and technology transfer. These countries have launched a range of policy reforms resulting in a more businessfriendly, enabling environment, including relaxing the prohibition of foreign land ownership. Globalization of transportation and communications and a reduction of formal trade barriers have added to the mix.

While it is impossible to provide an exact tally of the number of land deals and the sizes involved, estimates range from approximately 200 to 500 large deals covering as much as 50 million ha (Cotula et al, 2009; FAO, 2009; World Bank, 2010). However, it should be noted that there is a big difference between a public announcement and actually acquiring the land. For example, it takes time to negotiate the deal, finalize the transfer of rights and to start production. It is not unusual to take over four years from the start of negotiations to the start of output production.

While it is true that in many African countries there is abundant land available, for some states these land deals are taking away prime agricultural lands; and in the case of the DRC, almost half of the country's available land has been - or is scheduled to be - taken (Table 1). 
Table 1: Large Land Deals as Percentage of Domestic Agricultural Land

\begin{tabular}{|l|c|}
\hline & Percentage \\
\hline Madagascar & 6.7 \\
\hline Ethiopia & 8.2 \\
\hline Sudan & 2.3 \\
\hline Mozambique & 21.1 \\
\hline DR Congo & 48.0 \\
\hline
\end{tabular}

Source: Estimates from Global Land Project, 2010

It is interesting to note that the areas of sub-Saharan Africa that have the greatest land values are closely correlated with the areas with the largest amounts of land being taken. For example, there is an abundance of valuable land in the DRC and the Congo and both of these countries rank highest in the amount of land appropriated (see Maps 1 and 2).

\section{THE CUSTOM OF LAND TENURE IN SUB-SAHARNA AFRICA}

When the Europeans came, they had the Bible and we had the land; now we have the Bible and they have the land...

Formal land tenure is rare in the region. The World Bank estimates that only about 5\% of land - mostly urban - is held under land tenure title (World Bank, 2010). In many countries, the state owns most of the land - $80 \%$ in the case of Ghana, for example. Historically, many Africans saw land as being held in trust for both those who had come before and those yet to come. The concept of ownership was foreign and rare. In many areas, local chiefs look at themselves as the owners and most deals occur where land tenure is not strongly recognized and where governance is weak. While there have been significant advances in the legal recognition of indigenous lands and customary title, it is difficult for local residents to defend their rights against outside claims, and, of course, without formal land title, owners cannot use their land as collateral for loans (DeSoto, 2000).

With independence, You don't have to own the cow in order to milk it...

After independence, new governments kept the view that "unused" or "unclaimed" land was empty and available for sale. This viewpoint has added to the pressure to sell or lease vast tracts of land, even in recent years.

\section{CHARACTERISTICS OF THE DEALS}

It should be noted that there are wide variations across the region. While in Rwanda and Malawi almost all of the available cultivable land is occupied, there remain vast tracts available in Zambia, South Sudan and Mozambique. Despite differences in host country size, GDP, legal and political frameworks, and capacities to negotiate satisfactory deals, there is widespread similarity in the region regarding land transfers. They generally range from 10,000 to 100,000 hectares, and although some are much larger, they are usually leases, ranging from short-term to 99 years. Outright purchases are not common as a title transfer can be a difficult and lengthy process. The majority of deals lack transparency and until recently, there was little input from civil society, which can often result in corruption in the host country. Contracts generally lack the free, prior and informed consent of local inhabitants (Cuffaro and Hallman, 2011). Agreements lack transparency and, until recently, saw little input from civil society. Officials feel immune from public scrutiny which results in increased corruption in the host country (Cotula et al, 2009; FAO, 2009).

These deals are often part of complex packages (Cotula et al, 2009) and generally include incentives for the host country - employment opportunities, new or improved infrastructure, and technology transfer. Laws and rules are not uniformly enforced. Most occur where land tenure is not strongly recognized and whose governance is weak. Many contracts lack free, prior and informed consent (as required by Article 32 of the 2007 UN Declaration on the Rights of Indigenous Peoples) and often do not take into account local rights (Vermeulen and Cotula, 2010). Contracts are generally short with little compliance mechanisms. Low or no rent is charged in return for expected job creation. However, when charged, rates generally range from \$3-10 per hectare annually. 
Sometimes agricultural production is geared for export (the majority in Madagascar), for domestic consumption (Mali), or both (Ethiopia). About $40 \%$ of the land produces food crops, $21 \%$ cash crops, $20 \%$ biofuels, and the remainder plantation forestry, livestock and game reserves (FAO, 2009).

There are various financial and ownership arrangements which are usually very complex. The buyer (usually a single party) has the advantage over the seller. The seller (host party) is generally a government entity or (rarely) private land owner. There can be multiple players, little coordination, and low negotiation capacity. Investment agencies try to lure foreign investment, while other agencies try to maximize the benefits of the deal. There is often confusion and overlapping jurisdictions (central government, regional government, sector ministries, public agencies). Land data are also scattered across jurisdictions and agencies. As a result, the same land can be sold multiple times. Maps, if they exist, may be inaccurate. Contracts may contain "Stabilization clauses", whereby the host country cannot change the regulatory framework; i.e., environmental or labor concerns (Graham et al, 2011).

\section{INTRA-REGIONAL LAND GRABBING: SOUTH AFRICA'S RECENT INVOLVEMENT}

During 2010, Agri South Africa (the largest national farmer's association) was engaged in land acquisitions with 22 African governments and at least 16 operations underway in Mozambique, Malawi, Botswana and Kenya (Klienooi and Kooyey 2010). During the past three years, the South African government has signed bilateral investment treaties with Angola, Cameroon, DRC, Gabon, Guinea, Ethiopia, Madagascar, Mauritania, Namibia, Sudan, Tanzania, Zambia and Zimbabwe (Hall, 2011).

South African farmers and investment firms are looking for cheap land, labor, water and tax concessions. Most of the South African deals involve biofuels - jatropha for biodeiesel, sugarcane for bioethanol and others, including maize, soya and palm oil. Nearly half of the sugar processing factories in Southern Africa are South African owned.

The biggest South African deal so far is a 200,000 ha, 30-year lease of state-owned land in the Republic of Congo with the option of 10 million ha (Hall, 2011). Much of the land was occupied by small-holders with no land title. While ostensibly for local food production, the project will more likely be used for export to the European market, resulting in increased competition with local producers.

\section{IMPACTS}

There is little doubt that these large land deals can have a positive impact on local communities; more often, the results are negative. There is often arbitrary dispossession and locals who are rarely compensated adequately (or at all). Officials who approve expropriations sometimes sit on the appeals boards for those very transactions. Compensation can be in the form of resettlement on alternative (often poorer quality) land. Payment for very large projects usually goes directly to the central governments and rarely to local ones. This one-time payment results in an appreciation going only to the investor (especially when tax holidays have been tendered). There is little or no payment for secondary rights (eg, pastoralists or infrequent but habitual users). Women are generally left out of the equation. Payments are usually made to village headman and not to individuals. In addition, compensation may not include value placed on sacred grounds. These adverse affects result from a lack of legal knowledge (or literacy). There are little meaningful consultations with locals and who lack the trust of authority. Finally, as noted above, employment goals are seldom met (Cotula et al, 2009).

Because of growing concerns about the negative consequences of these large land deals, a number of international safeguard protocols and initiatives have been adopted in recent years (see Table 2 and Cuffaro and Hallman, 2011). It should be noted that some of these protocols are observed more strictly than others. 
Table 2: Recent Efforts to Safeguard Local Livelihoods and the Environment

\begin{tabular}{|l|l|}
\hline \multicolumn{1}{|c|}{ Protocol } & Date \\
\hline Equator Banks (to reduce social and environmental risks) & 2003 \\
\hline The Santiago Principles" (for Sovereign Wealth Funds) & 2008 \\
\hline Extractive Industries Transparency Initiative & 2002 \\
\hline Framework Guidelines on Land Policy (African Union) & 2009 \\
\hline Voluntary Guidelines for Tenure of Land and Associated & 2002 \\
Natural Resources (UN FAO) & 1992 \\
\hline Forest Stewardship Council & 2005 \\
\hline Better Cotton Initiative & 2006 \\
\hline Better Sugarcane Initiative & 2008 \\
\hline Roundtable on Sustainable Biofuels & \\
\hline
\end{tabular}

Host countries generally have poor governance and the capacity for meaningful negotiation and are illequipped to handle the intense competition for land (IIED, 2009). A deal can and often does result in a race to the bottom where short-term gains come at the expense of long-term interests. There are countless examples of population displacements and environmental degradation, especially with deforestization, loss of agribiodiversity, and access to water (Mitchell, 2010; World Bank, 2010). Increased population growth (average rate of 2.4\%) in subSaharan Africa will continue to put pressure on food security.

Even if financially successful for investors, many deals do not generate social benefits (increased pollution, land alienation, lower wages); and, even if the deals contain generous promised benefits for the host country, these countries are not equipped to monitor contract compliance.

\section{CONCLUSION}

Decisions made today can and do have long-term implications (up to 99 years in some cases) which need to be understood fully. Host countries generally have poor capacity for meaningful negotiation and cannot handle the intense competition for land. A deal can result in a race to the bottom where short-term gains come at the expense of long-term interests. Further, even if financially successful for investors, agreements may not generate social benefits. According to the FAO,

... the expansion of world trade in agricultural products has failed to translate into better living conditions for most of those working in farming in the developing world. (FAO, 2009)

Whether or not large-scale deals can benefit the local community will depend on a variety of inter-related factors, including tradition, land endowments, legal and enforcement capacities, the institutional framework, political stability, and the health of the economy and civil society (Cotula et al, 2009; World Bank, 2010).

While there are claims of "win-win", there are few examples of deals living up to the promises, but numerous ones that have not. Increased large land grabs have the potential to exacerbate social and political tensions in the fragile states in the region. For example, a proposed 1.3 million ha South Korean deal in Madagascar was a key factor in bringing down its president in 2009 (Cotula et al, 2009). It is critical for sub-Saharan African states to develop sound and transparent investment mechanisms, effective monitoring systems, and vigorous enforcement.

\section{AUTHOR INFORMATION}

Dr Donald Sparks is Professor of International Economics and Director of the Office of Fellowships at the Citadel in Charleston, South Carolina where he has been named outstanding MBA professor of the year three times. He also teaches at the Management Center Innsbruck in Austria. Before coming to the Citadel, Dr Sparks served as a Staff Assistant to Senator Ernest Hollings and later as the Regional Economist for Africa with the US Department of State's Office of Economic Analysis. A three-time Fulbright recipient, Dr Sparks received his BA from the George Washington University and his MA and PhD from the School of Oriental \& African Studies, University of London. E-mail: sparksd@citadel.edu 


\section{REFERENCES}

1. $\quad$ Alden, W L. "Whose Land Are You Giving Away, Mr President?" Paper presented at the Annual Bank Conference on Land Policy and Administration, World Bank, 2010.

2. Andrianirina-Ratsialonana, R.L., Ramarojohn, P., Burnod, P., and Teyssier, A. "After Daewoo? Current Status and Perspective of Large Scale Land Acquisition in Madagascar". Rome: International Land Coalition, 2011.

3. Benjaminsen, Toa, Bryceson, Ian, Maganfa, Faustin and Refseth, Tonje. "Conservation and Land Grabbing in Tanzania". Paper presented at the International Conference on Global Land Grabbing, Institute of Development Studies, University of Sussex, April 2011.

4. Berry, Sara. "Debating the Land Question in Africa". Comparative Studies in Society and History, Volume 44, 2002.

5. Bickel, M and Breuer, T. "DFI in Land in Developing Countries", Rural 21 The International Journal for Rural Development, volume 18, number 4, 2009.

6. Binswanger, H.P., Deininger, K and Feder, G. "Power, Distortions, Revolt and Reform in Agricultural Land Relations". In Handbook of Development Economics, ed. Behrman, T. and Srinivasan, T.N. North Holland: Elsevier 1995.

7. Braun, J, von and Meinzez-Dick, R. "Land Grabbing by Foreign Investors in Developing Countries: Risks and Opportunities". IFPG, Policy Brief 13, 2009.

8. Brown, T. "Contestation, Confusion and Corruption: Market-based Land Reform in Zambia, in Evers, E, Spierenburg, M and Wels, H (eds.), Competing Jurisdictions: Settling Land Claims in Africa, pp. 79-102. Leiden: Brill Academic Publishers, 2005.

9. Conway, D., Preschino, A., Ardoin-Bardin. S., Hamandawana, H., Dieulin, C and Mahe, G. "Rainfall and Water Resources Variability in Sub-Saharan Africa During the Twentieth Century", Journal of Hydrometerology, Volume 10, 2009.

10. Cotula, Lorenzo. "Land Deals in Africa: What is in the Contracts?", London: International Institute for Environment and Development, 2011.

11. Cotula, Lorenzo and Vermeulen, Sonja. "Deal or No Deal: The Outlook for Agricultural Land Investment in Africa". International Affairs, volume 85, number 6, 2009.

12. Cotula, Lorenzo, Vermeulen, Sonja, Leonard, Rebeca and Keeley, James. Land Grab or Development Opportunity? Agricultural Investments and International Land Deals in Africa. Rome: FAO, IIED and IFAD, 2009.

13. Cuffaro, Nadia and Hallam, David. "Land Grabbing in Developing Countries: Foreign Investors, regulation and Codes of Conduct". Paper presented at the International Conference on Global Land Grabbing, Institute of Development Studies, University of Sussex, April 2011.

14. Daniel, S and Mittal, A. The Great Land Grab: Rush for World's Farmland Threatens Food Security for the Poor. Oakland: The Oakland Institute, 2009.

15. Daniel, Shepard and Mittal, Anuradha. (Mis)investment in Agriculture: The Role of the International Finance Corporation in Global Land Grabs. Oregon: Oakland Institute, 2010.

16. Deininger, Klaus. "Challenges Posed by the New Wave of Farmland Investment". Journal of Peasant Studies, volume 83, number 2, 2011.

17. DeSchutter, Oliver. "How Not to Think of Land Grabbing: Three Critiques of Large-scale Investments in Farmland", Journal of Peasant Studies, Volume 38, Number 2, March 2011.

18. DeSchutter, Oliver. "Large Scale Land Acquisitions and Leases: A Set of Core Prioncipoles and Measures to Address Human Rights Challenge." Louvain: United Nations Special Rapporteir of rthe Right to Food, 2010.

19. deSoto, Hernan. The Mystery of Capital: Why Capitalism Triumphs in the West and Fails Everywhere Else. New York: Basic Books, 2000.

20. Dove, M. "Theories of Swidden Agriculture and the Political Economy of Ignorance", in Agroforestry Systems, Volume 1, 1983.

21. Dunning, J and Lundan, M. Multinational Enterprises and the Global Economy. Edward Elgar: Cheltenam.

22. Eickhout, B., van Mejil, H., Tabeau, A and Sthefest, E. "The Impact of Environmental and Climate Constraints on Global Food Supply". In Economic Analysis of Use in Global Climate Change Policy, ed. Hertel, T.W., Rose, S., Tol, R.S.J. London: Routledge, 2009. 
23. FAO. From Land Grab to Win-Win: Seizing the Opportunities of International Investment in Agriculture. Policy Brief \#4, Economic and Social Perspectives, 2009.

24. FAO. Irrigation in Africa in Fifures - Aquastat Survey 2005. Rome: Food and Agriculture Organization of the United Nations, 2005.

25. FAO, IFAD, UNCTAD and the World Bank Group. "Principles for Responsible Agricultural Investment That Respect Rights, Livelihoods and Resources", A Discussion Note, 2010.

26. Fischer, Gunter and Shah, Mahendra. "Farmland Investments and Food Security". Report prepared under a World Bank IIASA Contract, 2010.

27. Friends of the Earth. Africa: Up for Grabs: The Scale and Impact of Land Grabbing for Agrofuels. Brussels: Friends of the Earth, 2010.

28. German, Laura, Schoneveld, George and Mwangi, Esther. "Processes of Large-Scale Land Acquisitions by Investors: Case Studies from Sub-Saharan Africa". Paper presented at the International Conference on Global Land Grabbing, Institute of Development Studies, University of Sussex, April 2011.

29. Global Land Project. Land Grab in Africa: Emerging Land System Drivers in a Teleconnected World. Copenhagen: University of Copenhagen, 2010.

30. Graham, Alison, Aubrey, Sylvain, Kunnemann, Rolf and Suarez, Sofia. "The Role of the EU in Land Grabbing in Africa - CSO Monitoring 2009-1020 ‘Advancing African Agriculture,” The Impact of Europe's Policies and Practices on African Agriculture and Food Security". Paper presented at the International Conference on Global Land Grabbing, Institute of Development Studies, University of Sussex, April 2011.

31. GRAIN. Saudi Investors Poised to Take Control of Rice Production in Senegal and Mali?", March 2011.

32. IIED. "Land Grabs" in Africa: Can the Deals Work for Development? IIED Briefing Paper 2009.

33. Klienooi, K and Koyey, N. Review of Land Reforms in Southern Africa2010. Cape Town: Institute for Poverty, Land and Agrarian Studies, University of the Western Cape, 2010.

34. Kugelmann, M and Levenstein, S. "Land Grab? The Race for the World's Farmland". Washington, DC: Woodrow Wilson International Center for Scholars, 2010.

35. Hall, Ruth. "The Next Great Trek? South African Commercial Farmers Move North". Paper presented at the International Conference on Global Land Grabbing, Institute of Development Studies, University of Sussex, April 2011.

36. Hallam, D. "International Investment in Developing Country Agriculture: Issues and Challenges", Agriregionieuropa, Number 20, 2010.

37. Mabikke, Samuel. "Escalating Land Grabbing in Post-Conflict Regions of Northern Uganda: A Need for Strengthening Good Land Governance in Acholi Region". Paper presented at the International Conference on Global Land Grabbing, Institute of Development Studies, University of Sussex, April 2011.

38. Mann, H., and Smaller, C. "Foreign Land Purchases for Agriculture: What Impact on Sustainable Development? Sustainable Development Innovation Brief Number 8, 2010.

39. Mitchell, D. "Biofuels in Africa: Prospects for Sustainable Development". World Bank, Africa Region, 2010.

40. Nelson, G (et al). "Climate Change: Impact on Agriculture and Costs of Adaptation". Washington, DC: IFPRC, Food Policy Report, 2009.

41. Platteau, J.P. "Land Reform and Structural Adjustment in Sub-Saharan Africa: Controversies and Guidelines". Economic and Social Development Paper Number 107. Rome: FAO, 1992.

42. Rockstrom, J., Barron, J., and Fox, P. "Water Productivity in Rain-Fed Agriculture: Challenges and Opportunities for Smallholder Farmers in Drought-prone Tropical Agroecosysmets. In Kijne, J., et al, (eds) Water Productiviy in Agriculture: Limits and Opportunities for Improvement. London: CAB International, 2003.

43. Smaller, C and Mann, H. "A Thirst for Distant Lands: Foreign Investment in Agricultural Land and Water. International Institute for Sustainable Development, 2009.

44. Songwe, V and Deinenger, "Foreign Investment in Agricultural Production: Opportunities and Challenges. World Bank, Agricultural and Rural Development Notes, 2009.

45. United Nations. Norms on the Responsibilities of Transnational Corporations and Other Business Enterprises With Regard to Human Rights. E/CN.4/Sub.2/2003, 2003. 
46. Vermeulen, Sonja and Cotula, Lorenzo. Over the Heads of Local People: Consultation, Consent, and Recompense in Large-scale Land Deals for Biofuels Projects in Africa”. Journal of Peasant Studies, Volume 37, Issue 4, 2010.

47. Von Braun, J and Meinzen-Dick. "Land Grabbing” by Foreign Investors in Developing Countries: Risks and Opportunities. IFPRI Policy Brief 13, 2009.

48. Woodhouse, P and Ganho, A S. "Is Water the Hidden Agenda of Agricultural Land Acquisition in SubSaharan Africa?". Paper presented at the International Conference on Global Land Grabbing, Institute of Development Studies, University of Sussex, April 2011.

49. World Bank. Awakening Africa's Sleeping Giant: Prospects for Competitive Commercial Agriculture in the Guinea Savannah Zone and Beyond. Washington, DC: IBRD 2009.

50. World Bank. Rising Global Interest in Farmland: Can It Yield Sustainable and Equitable Benefits? Washington, DC: IBRD 2010.

51. Zoomers, Annelies. "Globalisation and the Foreignisation of Space: Seven Processes Driving the Current Global Land Grab”. Journal of Peasant Studies, Volume 37, Issue 2, 2010. 
MAP 1: Maximum Potential Value of Output for Africa (US\$ per Hectare)

Map A4.3.I Maximum Potential Value of Output for Africa (US\$ per hectare)

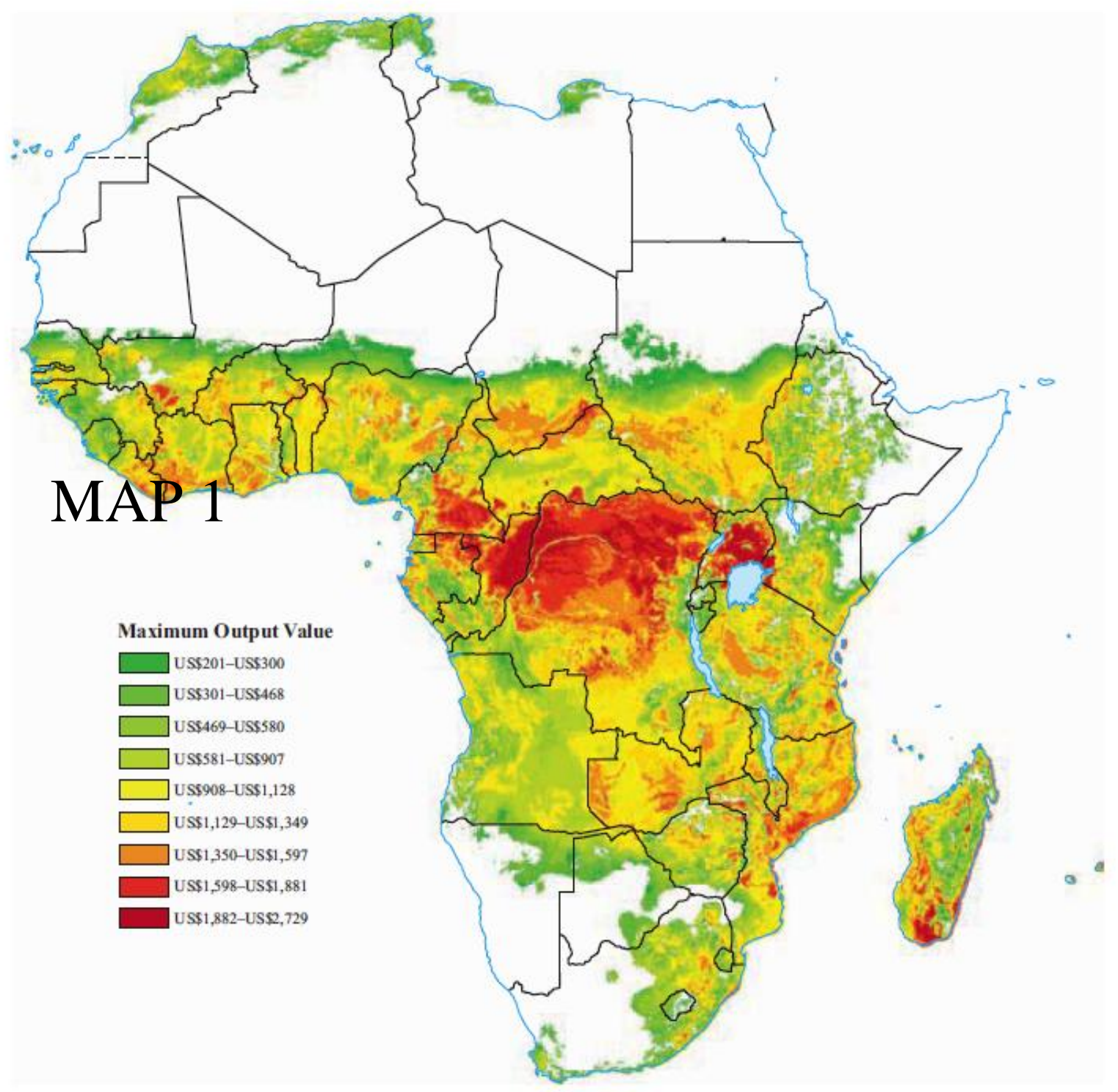

Source: Fischer and Shah 2010. 


\section{MAP 2: Number of Land Deals and Land Area}

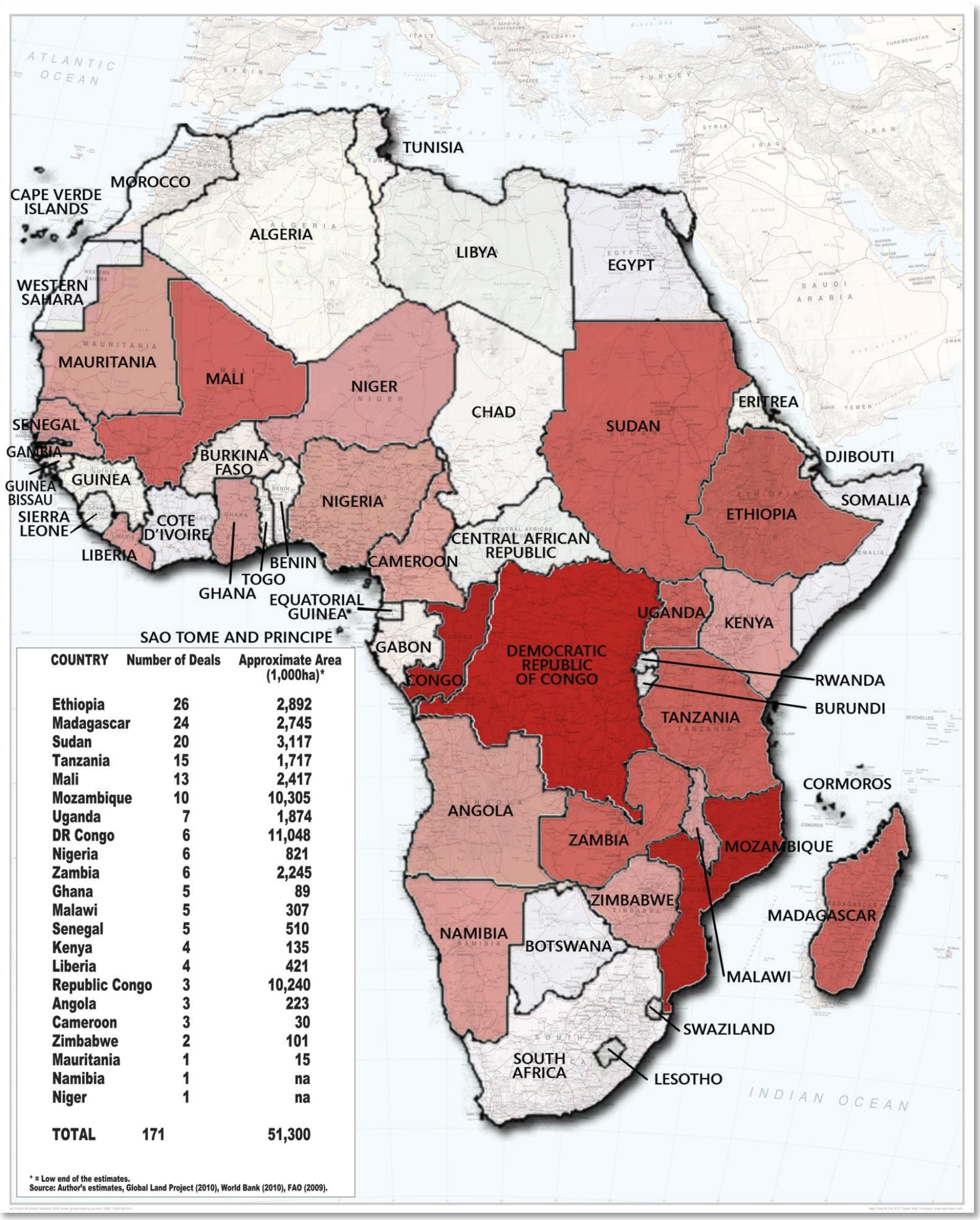

